\title{
GEOGRAPHICAL INVESTIGATIONS IN THE MANAGEMENT OF THE SVALBARD ENVIRONMENT
}

\author{
WIESEAW ZIAJA ๑ \\ Institute of Geography and Spatial Management, Jagiellonian University, Kraków, Poland
}

Manuscript received: April 24,2019

Revised version: July 15, 2019

\begin{abstract}
ZIAJA W., 2019. Geographical investigations in the management of the Svalbard environment. Quaestiones Geographicae 38(3), Bogucki Wydawnictwo Naukowe, Poznań, pp. 51-57. 4 figs.

ABSTRACT: The paper concerns specific features of exploration, geographical recognition, exploitation of natural resources, and economy of the archipelago. Development of the Svalbard system of nature protection areas and its impact on the environment and human activity is shown. Both the natural environment and Norwegian national interests are perfectly protected in Svalbard. Classical physico-geographical research was lost in significance to biological investigations (or to environmental science in the aspect of biotic components). Research activity in the human geography of Svalbard has mostly declined.
\end{abstract}

KEY WORDS: geographical investigations, environmental management, nature protection areas, Spitsbergen, Svalbard

Corresponding author:Wiestaw Ziaja, wieslaw.ziaja@uj.edu.pl

\section{Introduction}

Spitsbergen or Svalbard is a unique Arctic archipelago. Being uninhabited and primeval before its discovery by the Europeans, the archipelago was then developed entirely by them, in the socio-economic sense. Varied forms of exploitation and, after the $1^{\text {st }}$ World War, protection of natural resources have determined its development. Geographical investigations have played a great part in this complex process. The objective of this paper is to outline the significance of geographical research in succeeding stages of the socio-economic development of the archipelago. The elaboration is made based on many-sided literature referring to this topic and the author's own experiences collected during his research in Svalbard since 1982.

\section{Basic discovery and exploitation of life resources}

The discovery of Spitsbergen in AD 1596 in itself was a result of a geographical-commercial expedition financed by Dutch merchants and led by Barents (Rudmose Brown 1920). At that time, Spitsbergen was an entirely uninhabited archipelago, and later research (Bjerck 2000) confirmed that it had never been inhabited before. After Hudson's reports on the English expedition of 1607, Spitsbergen coasts, especially the western ones, began to be used for the location of ports for thousands of whalers from different Western European countries, and places for industrial treatment of their trophies (Fig. 1). The first stage of geographical recognition of the archipelago was achieved at that time. After the extermination of 


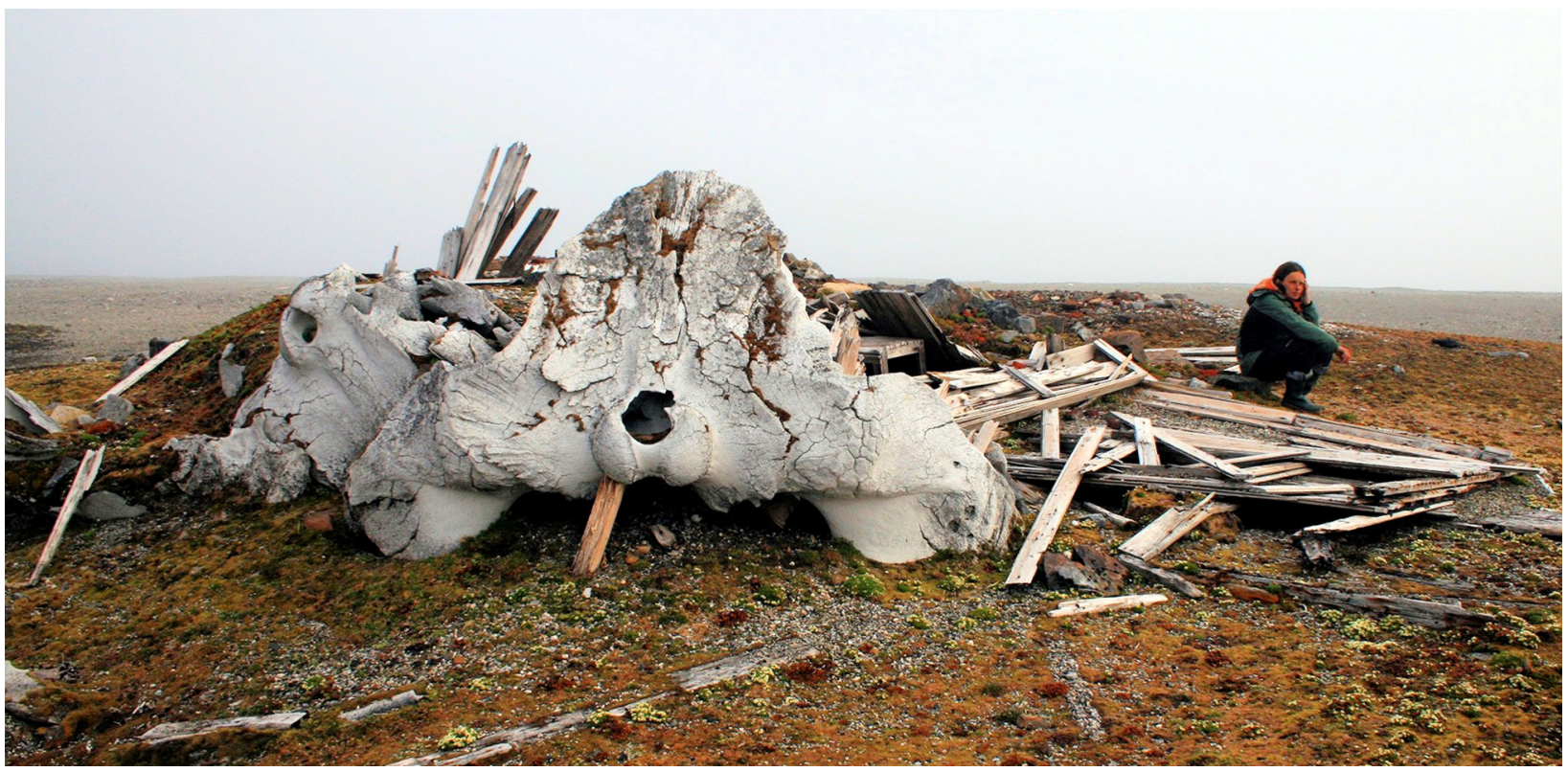

Fig. 1. Whale bones from the $17^{\text {th }}$ century on the Gåshamna bay, Sør-Spitsbergen National Park (Photo: J.Niedźwiecki 2008).

almost all the population of the Greenland whale (Balaena mysticetus), the Spitsbergen coasts deserted (Rudmose Brown 1920), but not completely. The Russian (Pomor) hunting industry stations were distributed sparsely but more regularly (also in the east) in the form of single huts or small settlements including a few huts with their infrastructure (Rudmose Brown 1920, Starkov et al. 2005). It is interesting when the Russian Pomors, coming first of all from the coasts of the White Sea, began their activity in Svalbard. According to Starkov et al. (2005) the Pomor activity started before the Barents' discovery, whereas, other sources (e.g. Chochorowski 1999) claim that it developed only after that discovery. Prior to the Russian hunters' departure in the middle of the $19^{\text {th }}$ century, the first Norwegian trappers had appeared at the end of the $18^{\text {th }}$ century. Since the $19^{\text {th }}$ century, they have dominated the local hunting activity (Rossnes 1993, Fig. 2). A big part of the geographical knowledge collected by hunters of different nationalities disappeared because they

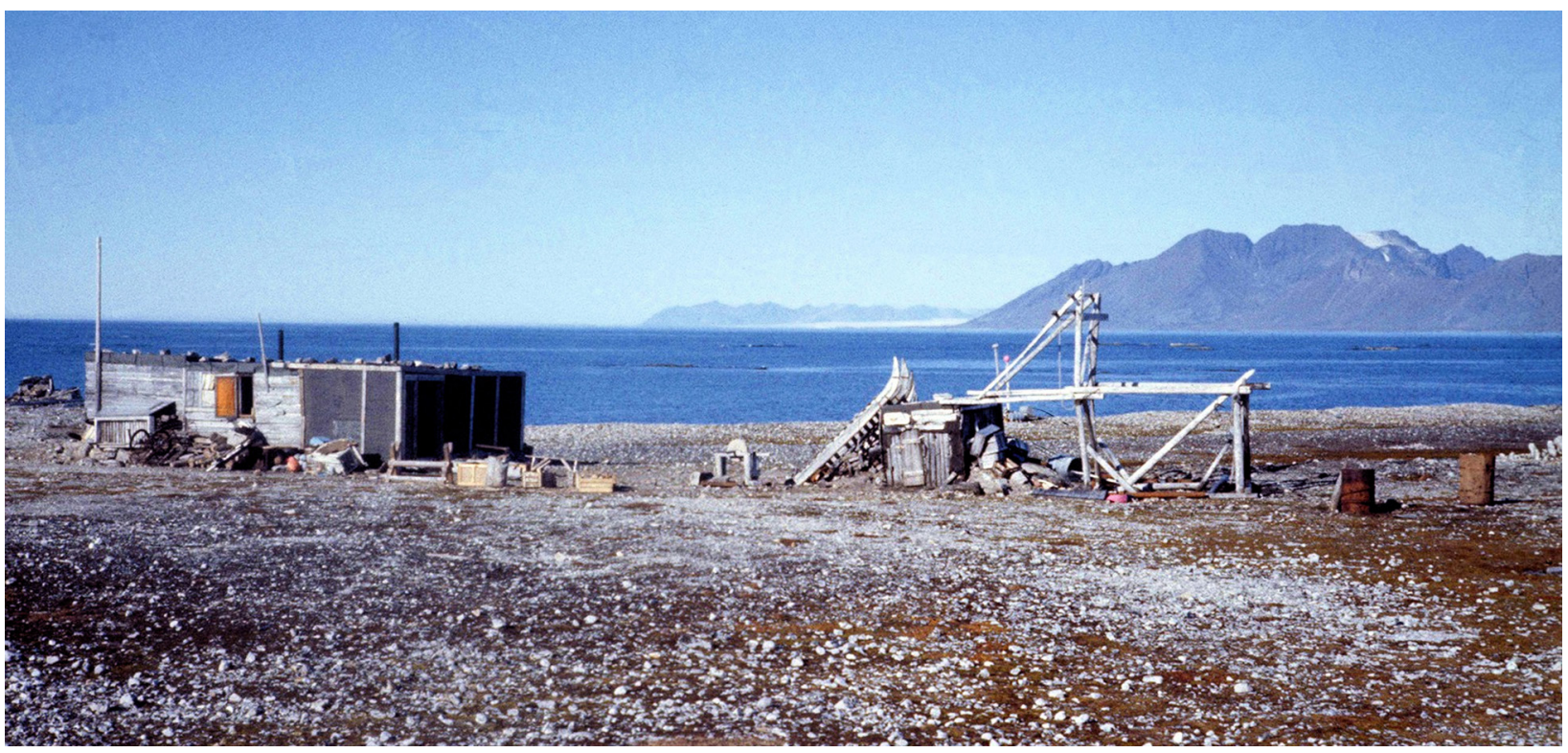

Fig. 2. Norwegian trapper station from the $20^{\text {th }}$ century near Palffyodden, Sør-Spitsbergen National Park, active until establishing the park in 1973 (Photo: W.Ziaja 1986). 
did not want to reveal the location of their hunting grounds (Rudmose Brown 1920). Moreover, they were interested mainly in the coasts and fisheries close to them, omitting, as a rule, inland areas. Besides, Russian documents on the Pomor industry were destroyed because of changing the famous Solovietskiy Monastery, which organized the industry, into an extermination camp in the 1920s.

\section{Scientific exploration and mining industry}

In the $19^{\text {th }}$ century, there was a huge progress in the scientific recognition of the archipelago: field expeditions from different scientific centres began. The majority of European states existing at that time took their part in these investigations. Good maps of the coasts of the archipelago were edited, e.g. an English map at a very general scale by Scoresby in 1820 (Isachsen 1920) and a more detailed Swedish map at a 1:600,000-1:700,000 scale by Dúner and Nordenskiöld (1865). Swedish and Norwegian scientific field investigations developed when Norway and Sweden were in personal union (under the same king) from 1814 to
1905. At the beginning of that period, Swedes prevailed, but the participation of Norwegians increased afterwards (Isachsen 1920). At the turn of the $19^{\text {th }}$ century, the Russian and Swedish academies of sciences organized a series of field expeditions, including wintering ones, in order to measure the length of the meridian arc along the eastern coasts of West Spitsbergen, the biggest island of the archipelago. The arrangement of triangular net (De Geer 1923a) resulted in a relatively wide exploration of its surrounding, not only of the coastal areas but also some inland ones. Precise topographical maps current for 1899-1900 at a scale of 1:50,000 (De Geer 1923 b) and 1:200,000 (Wassiliew 1907), being the result of those expeditions, made a huge progress in the quality of the island's cartographic picture. These maps are a very valuable material for today's comparative studies on the island landscape changes because the turn of the $19^{\text {th }}$ century became the end of the Little Ice Age with the maximum Holocene extent of glaciers. In contrast to earlier geographical investigations completed with biological recognition of fauna, the $19^{\text {th }}$ century research was associated with more and more detailed geological mapping. Hence, easily available deposits of coal were discovered. Their

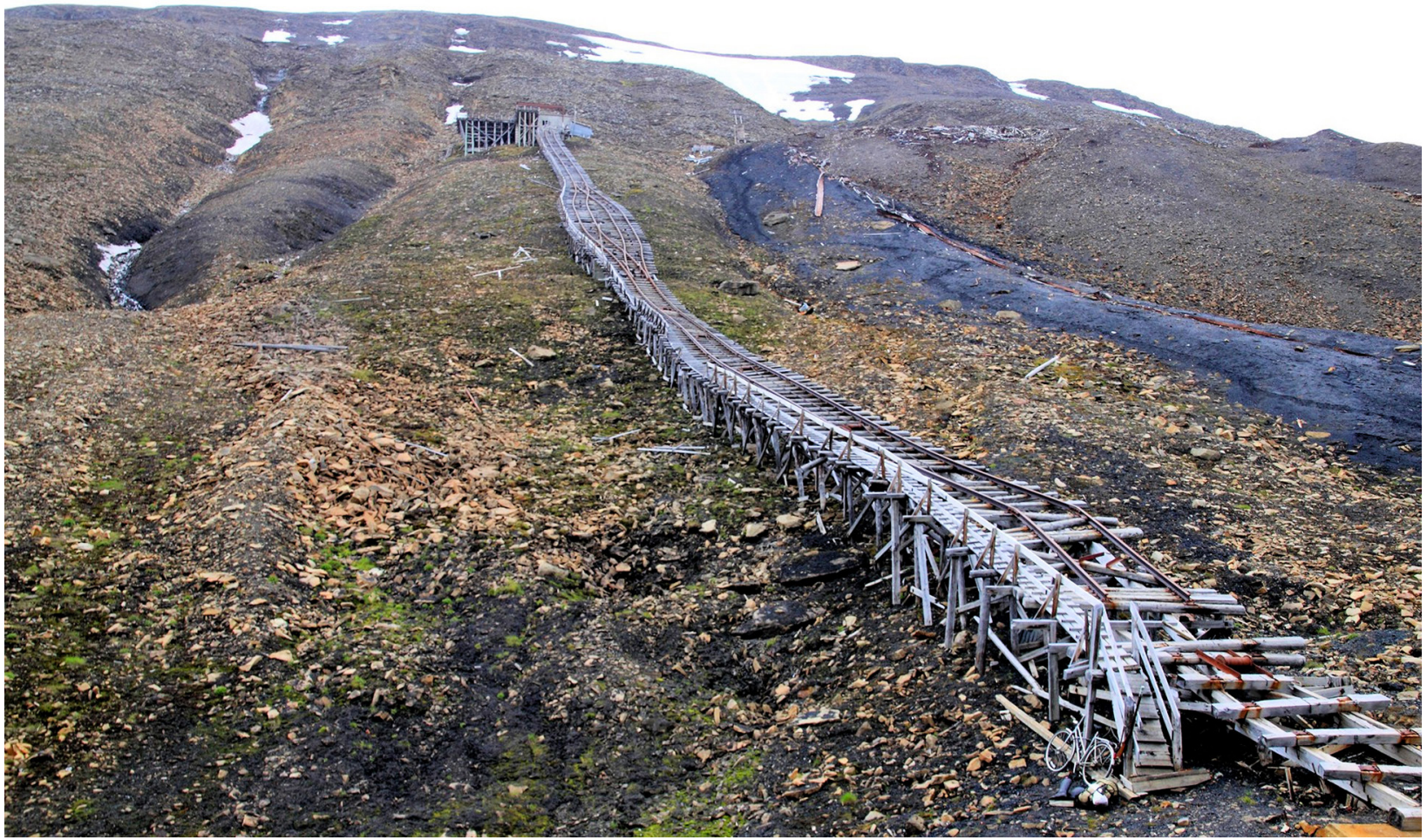

Fig. 3. Abandoned coal mine from the $20^{\text {th }}$ century in Endalen near Longyearbyen (Photo: W.Ziaja 2012). 
exploitation and export began in 1899 (Prestvold 2003). That industry determined the economic development of the archipelago that for the second time (after whaling in the $17^{\text {th }}$ century) began to give huge incomes to external investors. At that time, in the age of steam, coal was known as black gold. Its lack in other coasts of this part of the ocean secured demand for the local production. There was also a big advantage that steamships, which predominated among research vessels, could be supplied with coal just in Svalbard. That practice quickened the geographical exploration and recognition of the archipelago. Coal prospecting stimulated investigations of bedrock revealing other geological resources. However, the attempts of exploitation of them failed. The mining industry (Fig. 3) proved to be a main factor of location of coastal settlements (any inland ones have not appeared until today). Such settlements originated only on the western Spitsbergen coast, from Bellsund in the south to Kongsfjorden in the north, because very long sea ice season off the eastern and northern coasts ruled out profitable mining activity there. After the age of coal as a main fuel, especially in the sea transport, its production has been decreasing progressively since the end of the $1^{\text {st }}$ World War. Between the $1^{\text {st }}$ and $2^{\text {nd }}$ World Wars, the small mining settlements have been closed down. After the $2^{\text {nd }}$ World War, some big mining settlements have also been closed down: in the 1960s, Grumantbyen was abandoned and coal mining in Ny Álesund was stopped (Hisdal 1976), afterwards, Ny Álesund has been changed into an international set of scientific stations; in the 1990s, Piramiden was abandoned. In Svea, coal is still mined but there is no permanent urban population. Nowadays, there are only three active coalmines in Svalbard - in Longyearbyen (Andventdalen), Barentsburg and Svea. Buildings (in a varied state of preservation) have remained after the mining activity in many other places of the main island of the archipelago. Some of them have been adapted for scientific or hunting purposes.

\section{Norwegian sovereignty and international scientific collaboration}

After the $1^{\text {st }}$ World War, in 1920 , the Spitsbergen Archipelago was given to Norway in virtue of the so-called Paris Treaty between nine states. Afterwards, next 30 states, including Poland, have joined this treaty (Spitsbergen Treaty 1920). Soon, Norway has changed the Dutch (given by Barents) name of the archipelago into (Nordic) Svalbard and the name of its biggest island from West Spitsbergen to Spitsbergen. Norway had the sovereign right to do that. However, Norway has accepted many limitations of the sovereignty, namely (among others) that:

1. Ships and nationals of all the treaty parties shall enjoy equally the rights of fishing and hunting in the territories and territorial waters of the archipelago, and occupiers of land (...) will enjoy the exclusive right of hunting on their own land (article 2 of the treaty).

2. The nationals of all the treaty parties shall have equal liberty of access and entry for any reason or object whatever to the waters, fjords and ports of the archipelago (...); subject to the observance of local laws and regulations, they may carry on there without impediment all maritime, industrial, mining and commercial operations on a footing of absolute equality; Norwegian nationals, ships or goods being (...) not treated favourably in any respect (article 3).

3. Norway undertakes not to create nor to allow the establishment of any naval base (...) and not to construct any fortification on the archipelago which may never be used for warlike purposes (article 9).

Simultaneously, the treaty let Norway protect environment of the archipelago: Norway shall be free to maintain, take or decree suitable measures to ensure the preservation and, if necessary, the reconstruction of the fauna and flora (article 2 of the treaty). This short statement had given Norway a chance to omit the aforementioned limitations of the sovereignty in the areas (and waters) within areas and activities of nature protection that could be undertaken in future.

In 1925, the Svalbard Act was passed. After that, several animal species were taken under protection. In 1932, two first plant protection areas were established (Overrein 2008).

Of course, the Norwegians have intensified their investigations, especially the geographical ones, of the archipelago since the 1920s. A special scientific institution - Norges Svalbard- og Ishavsundersøkelser (Norway's Investigations of Svalbard and the Arctic Sea) - was established 
in 1928, and began publishing results of its research works. After the $2^{\text {nd }}$ World War, in 1948, this institution has been transformed into the Norwegian Polar Institute (Norsk Polarinstitutt), very active until today. Problems of the Earth sciences, especially the geographical and geological ones, predominated in the institute's research activity until the 1990s. During that time, the complete topographical and geological maps (in many sheets) of the Svalbard Archipelago at a scale 1:100,000 were elaborated and edited, and many basic investigations from different physico-geographical disciplines were done. In many areas, especially in the western Spitsbergen, the research was carried out at a detailed scale (bigger than 1:100,000). It is worth noticing that the institute carried out a wide collaboration with foreign scientists of different specializations, including geographers, very often directly (without arduous bureaucracy connected with the intervention of other institutions). Many geographers - especially from my generation - took part in that collaboration which was very effective for both parties.

In the 1960s, the idea of nature protection areas in Svalbard began to be elaborated on the base of the results of investigations that were carried out by the Norsk Polarinstitutt since the 1920s. An increasing interest in petroleum and natural gas prospecting, traditional coal mining and tourist industry were taken into account. The idea was realized in 1973 when two huge nature reserves (Nordaust-Svalbard, SøraustSvalbard), three large national parks (NordvestSpitsbergen, Forlandet, Sør-Spitsbergen) and fifteen bird reserves were established (Ministry of Environment 1984). The main objective of the protection resolutions in 1973 was to protect the areas and their interconnected wildlife and flora, for their intrinsic value and for scientific and educational purposes because they belong to the last untouched ecosystems left on Earth (Overrein 2008). That demanded strong restrictions on the exploitation of the protected areas (Overrein 2008). Moffen Nature Reserve for walrus was added in 1983 (Protected areas in Svalbard 2010). This system of protected areas was very effective, maybe because it was based (intentionally or incidentally) on the source-sink model (Farina 2000) in which the national parks and nature reserves, in the outskirts of Svalbard, were the

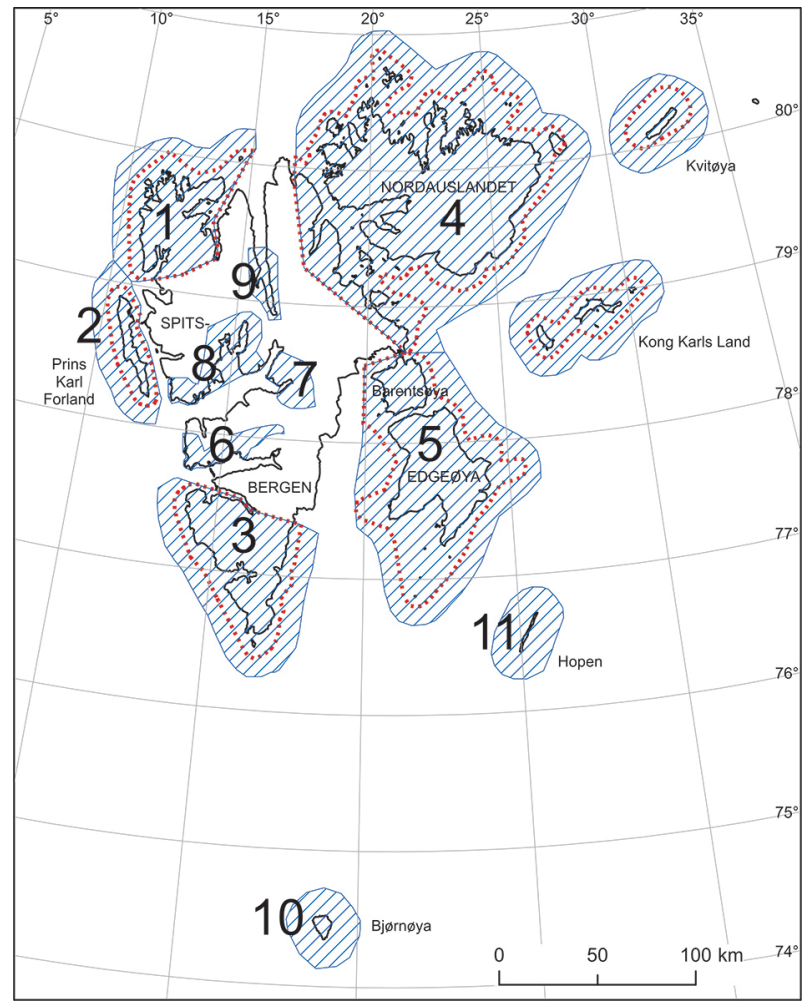

Fig. 4. Large protected areas in Svalbard. Their boundaries from 1973 are singed with the red dotted line, their current extent is hachured. In 2004, the extent of territorial water was widened from 4 to 12 nautical miles, enlarging the protected areas. Elaborated on the basis of: Ministry of Environment 1984, Protected areas in Svalbard 2010.

National parks established in 1973: 1 - Nordvest-Spitsbergen, 2 - Forlandet, 3 - Sør-Spitsbergen. Nature reserves established in 1973: 4 - Nordaust-Svalbard, 5 - Søraust-Svalbard. National parks established in 2003-2005: 6 - Nordenskiöld Land, 7 - Sassen-Bünsow, 8 - Nordre Isfjorden, 9 - Indre Wijdefjorden. Nature reserves established in 2002-2003: 10 - Bjørnøya, 11 Hopenøya.

sources exporting a surplus of animals to the sink absorbing this surplus in the central part of Spitsbergen (Fig. 4).

In 1975, an all-year airport began its regular service in Longyearbyen (Hisdal 1976).

\section{Last changes in the Norwegian policy and environmental management}

Unfortunately, the predomination of Earth sciences, with a strong position of geography, finished in the second half of the 1990s when Storting (the Norwegian Parliament) decided to move the Norwegian Polar Institute from Oslo 
to Tromsø, i.e. more than $1000 \mathrm{~km}$ closer to the Arctic (but further off the Antarctic which is also the research area for the institute). In reaction to that, the overwhelming majority of the institute employees resigned. They were replaced mainly by biologists (there has never not been any faculty of geography in the University of Tromsø). Due to that re-organization, in 1997-1998, the Norsk Polarinstitutt began to be a mainly biological institute (however, preserving its interdisciplinary character). Oceanography and marine geology became much more important within the minority representation of Earth sciences, due to their connections with biological marine science. Surely, that is most disadvantageous for the development of physico-geographical research on the archipelago land areas.

Since the 1950s, Svalbard has became a popular study area for physico-geographical research expeditions of leading universities or academic institutes from many states, including Norway. They are not a subject of this paper because influence of their scientific results on the Svalbard environmental management might be indirect only, because the Norwegian authorities did not plan them. International collaboration is very important for effectiveness of such activities. For example, there are cooperative physico-geographical projects between Norwegian and Russian scientists, especially from the Institute of Geography, Russian Academy of Sciences. Several Polish universities (University of Silesia, Jagiellonian University in Kraków, University of Wrocław, Adam Mickiewicz University in Poznań, Nicolaus Copernicus University in Torun, and Maria CurieSkłodowska University in Lublin) are active in this field too (RIS 2019). Polish physico-geographical investigations in Svalbard are also supported by the Institute of Geophysics, Polish Academy of Sciences (Zwoliński et al. 2013).

There is a surprising lack of current studies both Norwegian and foreign ones - from many areas of human geography of Svalbard in spite of a big demand for them. In Norway, that is a result of a crisis in human (social-economical) geography, which appeared as early as by end of the 1980s. Therefore, its separation from the Earth sciences (and consistently from physical geography) resulted in a decline of the majority of its centers in Norwegian universities and other academic schools (in the remaining centers, the function of human geography was reduced to an ancillary one).

Since the 1980s, the archipelago has become a popular tourist destination, especially in summer. Some 60,000 people visited Svalbard in 2008 (Protected Areas in Svalbard 2010).

In 1998, the Svalbard system of protected areas was evaluated (Overrein 2008). Why at that time? Maybe because the 1990s were the time in which Russia was in the deepest crisis. In any case, the evaluation revealed among other things that the most biologically productive and species-rich land areas in the archipelago were also the most weakly represented areas among those that received protection in 1973 (Overrein 2008). It is worth noticing that according to Act of 15 June 2001 No. 79 Relating to the Protection of the Environment in Svalbard (Government.no 2001) the protected areas should include the full diversity of natural habitats and landscapes, which is also a very geographical and not only biological reason (protection rather of areas than species). The new system of Svalbard protected areas, passed in 2003 and implemented in 2004, has been completed with three new national parks in the middle Spitsbergen: Nordenskiöld Land, Sassen-Bünsow, Nordre Isfjorden. In 2005, a fourth national park, Indre Wijdefjorden, was added. Three new nature reserves were also established: Bjørnøya in 2002, and Hopenøya and Ossian Sars in 2003. In 2004, the extent of territorial water was widened from 4 to 12 nautical miles, enlarging the area of protection (Protected areas in Svalbard 2010, Fig. 4). Apart from the aforementioned ones, the protected areas include small biotopes or biotope protection areas (i.e. 15 aforementioned bird reserves or sanctuaries) and one geotope protection area. These current protected areas cover $65 \%$ of Svalbard's land area and $86.5 \%$ of territorial water surrounding Svalbard (Protected areas in Svalbard 2010). A rhetoric question can be given: Do not such large protected areas make fiction of the majority of the aforementioned limitations of Norwegian sovereignty over the archipelago? After all, the Norwegian authorities have the right to control and even to forbid any human activity in the majority areas and waters of the Svalbard archipelago. 


\section{Recapitulation}

The following conclusions on the current state of the Svalbard affairs can be drawn from the above analysis:

1. At the beginning of the $21^{\text {st }}$ century, the right to preservation of the fauna and flora was effectively used for the omitting a lot of limitations of the Norwegian sovereignty over the archipelago, included in the Spitsbergen Treaty.

2. Both the natural environment and Norwegian national interests are perfectly protected in Svalbard.

3. Classical physico-geographical research was lost in significance (and financial support) to biological investigations (or to environmental science in the aspect of biotic components).

4. There is a need for multidisciplinary international environmental projects and geographical science should take a leading role in them.

5. Research activity in the human geography of Svalbard has mostly declined.

\section{Acknowledgements}

Reviewers are thanked for their notes. A. Kasprzak is thanked for his assistance in proofreading the text. K. Ostafin is thanked for his assistance in drawing figure 4 .

\section{References}

Bjerck H.B., 2000. Stone Age settlement on Svalbard? A re-valuation of previous finds and the results of a recent field survey. Polar Record 36(197): 97-112.

Chochorowski J., 1999. Problemy dendrochronologii rosyjskich stacji towieckich na Spitsbergenie. Uniwersytet Jagielloński, Instytut Archeologii, Oficyna Cracovia, Kraków.

De Geer G., 1923a. Plan öfver det svensk-ryska gradmätningsnätet på Spetsbergen öfver nyaste mätningar sammanstäld af Gerard De Geer Maj 1900.1:1000,000. In: Measure D'un Arc de Méridien au Spitsberg, Entr. en 18991902, Description Topographique de la Région Explorée. Géologie. Stockholm (map).

De Geer G., 1923b. Pl. F. Environs de la Station Russe D'Hivernage. In: Measure D'un Arc de Méridien au Spitsberg, Entr. en 1899-1902, Description Topographique de la Région Explorée. Géologie. Stockholm (map 1:50,000).

Dúner N., Nordenskiöld A.E., 1865. Karta öfver Spetsbergen, hufvudsakligast enligt iakttagelser under de sven- ska expeditionerna åren 1861 och 1864. In: Anteckningar Spetsbergens Geografi. Kongl. Svenska Vetenskaps-Akademiens Handlingar, Bandet 6, N:o 5; P.A. Norstedt \& Söner, Kogl. Boktryckare, Stockholm (map 1:600,000$700,000)$.

Farina A., 2000. Landscape ecology in Action. Kluwer Academic Publishers, Dordrecht, Boston, London.

Government.no [Information from the Government and the Ministries], 2001. Act of 15 June 2001 No. 79 Relating to the Protection of the Environment in Svalbard. Online: www. regjeringen.no/en/doc/laws/Acts/Svalbard-environmental-protection-act.html?id=173945 (accessed 20 April 2019).

Hisdal V., 1976. Geography of Svalbard. A short survey. Norsk Polarinsitutt, Polarhåndbok Nr. 2, Oslo.

Isachsen G., 1920. Norske fangstmænds og videnskapsmænds indsats $i$ utforskningen av Spitsbergen-ogruppen i nyere tid. Naturen 44: 68-85.

Overrein Ø., 2008. Svalbard protected areas. In: Cruise Handbook for Svalbard, Norsk Polarinstitutt. Online: cruise-handbook.npolar.no/en/svalbard/protected-areas.html (accessed 20 April 2019).

Ministry of Environment, 1984. Environmental Regulations for Svalbard and Jan Mayen. Ministry of Environment, Oslo.

Prestvold K., 2003. Isfjorden. A journey through the nature and cultural history of Svalbard. Sysselmannen på Svalbard, Longyerbyen.

Protected areas in Svalbard, 2010. Protected areas in Svalbard - securing internationally valuable cultural and natural heritage. Norwegian Directorate for Nature Management, Norsk Polarinstitutt, Riksantikvaren, Sysselmannen Svalbard.

RIS [Research in Svalbard Database], (n.d.). Online: www. researchinsvalbard.no (accessed 20 April 2019).

Rossnes G., 1993. Norsk overvintringsfangst på Svalbard 1895 1940. Norsk Polarinstitutt Meddelelser 127: 1-195.

Rudmose Brown R.N., 1920. Spitsbergen. An Account of Exploration, Hunting, the Mineral Riches \& Future Potentialities of an Arctic Archipelago. Seeley, Service \& Co. Limited, London.

Spitsbergen Treaty, 1920. Treaty between Norway, The United States of America, Denmark, France, Japan, the Netherlands, Great Britain and Ireland and the British overseas Dominions and Sweden concerning Spitsbergen signed in Paris $9^{\text {th }}$ February 1920. Online: en.wikisource.org/wiki/Spitsbergen_ Treaty (accessed 20 April 2019).

Starkov V.F., Chernosvitov P.J., Derzhavin V.L., Zakharov V.G., Zvyagin V.N., Sharin V.V., 2005. Materyalnaya kultura russkikh Pomorov po dannym issledovanij na arkhipelage Shpicbergen. Vyp. II. Poseleniya i pogrebleniya. Naucznyj Mir, Moskva.

Wassiliew A.S., 1907. Spitsberg II. Feuille du Milieu. In: Missions scientifiques pour la Mesure d'un arc de Méredien au Spitsberg entreprises en 1899-1902 sous les auspices des gouvernements Russe and Suédois. Mission Russe. Imprimerie de $l^{\prime}$ Académie Impériale des Sciences, St. Pétersbourg (map 1:200,000).

Zwoliński Z., Kostrzewski A., Pulina M. (eds.), 2013. Dawne i wspótczesne geoekosystemy Spitsbergenu / Ancient and modern geoecosystems of Spitsbergen. Bogucki Wydawnictwo Naukowe, Poznań. 